\title{
Cadmium (Cd) and Nickel (Ni) Distribution on Size-Fractioned Soil Humic Substance (SHS)
}

\author{
Sheng-Hsien Hsieh ${ }^{1}$, Teng-Pao Chiu ${ }^{1}$, Wei-Shiang Huang ${ }^{2}$, Ting-Chien Chen ${ }^{2}$ and \\ Yi-Lung Yeh ${ }^{1, *}$ \\ 1 Department of Civil Engineering, National Pingtung University of Science and Technology, Pingtung 91201, \\ Taiwan; tino388@yahoo.com.tw (S.-H.H.); ctp5559@gmail.com (T.-P.C.) \\ 2 Department of Environmental Science and Engineering, National Pingtung University of Science and \\ Technology, Pingtung 91201, Taiwan; stefsun921015@yahoo.com.tw (W.-S.H.); \\ chen5637@mail.npust.edu.tw (T.-C.C.) \\ * Correspondence: yalung@mail.npust.edu.tw; Tel: +886-8-774-0425; Fax: +886-8-774-0122
}

Received: 20 July 2019; Accepted: 9 September 2019; Published: 13 September 2019

check for updates

\begin{abstract}
Soil humic substances (SHS) are heterogeneous, complex mixtures, whose concentration, chemical composition, and structure affect the transport and distribution of heavy metals. This study investigated the distribution behavior of two heavy metals [cadmium (Cd) and nickel (Ni)] in high molecular weight SHS (HMHS, $1 \mathrm{kDa}-0.45 \mu \mathrm{m}$ ) and low molecular weight SHS (LMHS, $<1 \mathrm{kDa}$ ) extracted from agricultural soils. The HMHS mass fractions were $45.1 \pm 19.3 \%, 17.1 \pm 6.7 \%$, and $57.7 \pm 18.5 \%$ for dissolved organic carbon (DOC), $\mathrm{Cd}$, and Ni, respectively. The metal binding affinity, unit organic carbon binding with heavy metal ratios ([Me]/[DOC]), were between $0.41 \pm$ $0.09 \mu \mathrm{mol} / \mathrm{g}-\mathrm{C}$ and $7.29 \pm 2.27 \mu \mathrm{mol} / \mathrm{g}-\mathrm{C}$. Cd preferred binding with LMHS $(p<0.001)$, while Ni preferred binding with HMHS $(p<0.001)$. The optical indicators $\mathrm{SUVA}_{254}, \mathrm{~S}_{\mathrm{R}}$, and FI were $3.16 \pm 1.62$ $\mathrm{L} / \mathrm{mg}-\mathrm{C} / \mathrm{m}, 0.54 \pm 0.18$ and $1.57 \pm 0.15$, respectively for HMHS and $2.65 \pm 1.25 \mathrm{~L} / \mathrm{mg}-\mathrm{C} / \mathrm{m}, 0.40 \pm 0.17$, and $1.68 \pm 0.12$, respectively for LMHS. The HMHS contained more aromatic and lower FI values than LMHS. Multilinear regression showed a significant positive correlation between the measured predicted $[\mathrm{Me}] /[\mathrm{DOC}]$ ratios $(\mathrm{r}=0.52-0.72, p<0.001)$. The results show that the optical indices can distinguish the chemical composition and structure of different size SHS and predict the binding ability of Me-SHS.
\end{abstract}

Keywords: soil humic substances (SHS); cadmium and nickel; SHS separation; [Me]/[DOC] ratios; optical indicators; multilinear regression

\section{Introduction}

Soil organic matter (SOM) is an important component of soil [1-4]. Heavy metals in soil are mainly associated with SOM and fine particles, such as oxide-type components and clay minerals [1,5-7]. The SOM's major components are soil humic substances (SHS). The SHS is a heterogeneous and complex organic substance comprised of various functional groups such as phenol, carboxyl, and hydroxyl functional groups [1,5,7-10], which have a strong ability to bind heavy metals. When heavy metals bind with SHS, the complex affects the heavy metal mobility, biotoxicity, and fate in the soil environment $[1,4-7,9,10]$.

The SHS concentration (represented by C content); however, does not fully predict the mobility potential and binding strength of metals. The SHS chemical composition, structure, and molecular weight are important factors that affect the Me-SHS binding capacity. In strongly-binding Me-SHS complexes, metals are stable and will not readily release; this reduces the metal mobile potential and biological toxicity. However, in a weakly-binding Me-SHS complex, metals may release into the 
environment and affect ecological safety and security, and inhibit crop growth [1,7,9-12]. Several studies have used the metal binding affinity $[\mathrm{Me}] /[\mathrm{DOC}]$ ratio to understand the preferences, distribution, bioavailability, and mobile potential of metal binding with dissolved organic matters (DOM) and SHS $[1,9,10,13-15]$.

The SHS has a wide range of molecular weights [1,2]. The SHS composition and molecular weight are greatly influenced by the source of the organic matter and the biogeochemical processes in the soil $[1,2,11,16]$. The SHS molecular weight may play an important role in heavy metal binding. A molecular weight of $1 \mathrm{kDa}$ is a common quantity used to distinguish high and low molecular weight of DOM and SHS. Hence, in this study, SHS molecular weight less than $1 \mathrm{kDa}$ was designated as the low molecular weight SHS (LMHS), and the molecular weight higher than $1 \mathrm{kDa}$ was designated as the high molecular weight SHS (HMHS). It is worth noting that the LMHS still contained various heavy metal species (free ion metals, binding with low molecular weight SHS) [17-23]. Moreover, the low molecular weight DOM and SHS had a metal and hydrophobic organic compound binding capacity [24-26].

Previous studies on the distribution and partition of metals between high and low molecular weight organic matter focused on the DOM in an aquatic environment $[17,21-23,27-29]$ and a few studies focused on soil solutions [18]. The optical indices were used to examine the influencing factors of the $[\mathrm{Me}] /[\mathrm{DOM}]$ ratio, including a water/calcium chloride $\left(\mathrm{CaCl}_{2}\right)$-extracted soil solution and soil leachate $[9,10]$ as well as bulk water DOM [13-15]. The widely-ranging SHS molecular weights had different chemical compositions and structure, which may have affected the Me-SHS binding behavior. Information on the distribution and partition of heavy metals in HMHS and LMHS separated by SHS is still lacking.

Optical methods (UV/Vis and fluorescence spectroscopy) are rapid, sensitive, non-destructive methods used to investigate DOM and SHS chemical composition and structure [30-36]. This study investigated (1) heavy metals ( $\mathrm{Cd}$ and Ni) distribution in alkaline-extracted soil humic substances (BHS), and both size-fractioned HMHS (1 kDa-0.45 $\mu \mathrm{m})$ and LMHS ( $<1 \mathrm{kDa}),(2) \mathrm{UV}$-Vis and fluorescence indices $\left(\mathrm{SUVA}_{254}, \mathrm{~S}_{\mathrm{R}}\right.$, and FI) used to investigate BHS, HMHS and LMHS chemical composition and structure, and (3) the correlation method examining the $[\mathrm{Me}] /[\mathrm{DOC}]$ ratio-affecting factors in term of the SHS optical indicators.

\section{Research Method and Material}

\subsection{Site Description and Soil Sampling, Treatment, and Measurement}

The study site was located in a paddy experimental field in southern Taiwan (location $23^{\circ} 12^{\prime} 39.5^{\prime \prime} \mathrm{N}$, $120^{\circ} 10^{\prime} 54.0^{\prime \prime} \mathrm{E}$ ). The soil samples were taken with an auger (ID $5 \mathrm{~cm}$ ) to $60 \mathrm{~cm}$ depth and about $2.0 \mathrm{~kg}$ was taken for each sample. Eight soil samples were collected from the sampling site each time. In total, 24 soil samples were used to analyze the concentration and optical values of the SHS and heavy metals.

The soil samples were air-dried (about one week) in the laboratory. The soil was passed through a sieve mesh \#10 (2.0 mm) and provided for subsequent tests. The basic properties of the soil were measured with the sieved soil ( $\mathrm{pH}$, and organic matter $(\mathrm{OM}))$. The soil contained $46 \%, 33 \%$, and $21 \%$ sand, silt, and clay, respectively and was classified as loam soil. The soil $\mathrm{pH}$ was $8.07 \pm 0.38$ and the $\mathrm{OM}$ was $2.28 \pm 0.09 \%$. The total metal concentrations ( $\mathrm{Fe}, \mathrm{Mn}, \mathrm{Cd}, \mathrm{Cr}, \mathrm{Cu}, \mathrm{Ni}$, and $\mathrm{Zn}$ ) were analyzed with an aqua regia digestion method. Three $\mathrm{g}$ soil was added in $30 \mathrm{~mL}$ aqua regia solution; after $16 \mathrm{~h}$ settling and $2 \mathrm{~h}$ digestion at $180^{\circ} \mathrm{C}$, the solution was measured as $100 \mathrm{~mL}$. Alkaline metals $(\mathrm{Ca}, \mathrm{Mg}, \mathrm{K}$, and $\mathrm{Na}$ ) were extracted with a $1.0 \mathrm{M}$ ammonium acetate solution at soil mass/volume $=1 / 10$.

\subsection{HS Extraction and Separation}

Bulk SHS (BHS) was extracted with an alkaline solution. Briefly, $5 \mathrm{~g}$ soil was added to $0.1 \mathrm{~N}$ $\mathrm{HCl} 100 \mathrm{~mL}$ solution to remove alkaline metals and carbonate. The $100 \mathrm{~mL}$ of $0.1 \mathrm{~N} \mathrm{NaOH}$ was added to the residual soil at the $\mathrm{W} / \mathrm{V}=1 / 20$. After $24 \mathrm{~h}$ shaking, the soil solution was centrifuged at $4500 \mathrm{rpm}$ for $30 \mathrm{~min}$. The $\mathrm{NaOH}$-extracted humic substance was identified as the bulk SHS (BHS) 
solution. A three-liter BHS solution was used to separate the HMHS and LMHS fractions. A cross-flow ultrafiltration system equipped with $1 \mathrm{kDa}$ nominal molecular weight cutoff ceramic membrane cartridges (Filtanium, France, membrane area $320 \mathrm{~cm}^{2}$ ) was used to separate the high molecular weight SHS (HMHS, $1 \mathrm{kDa}-0.45 \mu \mathrm{m}$ ) and the low molecular weight SHS (LMHS, $<1 \mathrm{kDa}$ ). The feed flow rate was $1.7-2.0 \mathrm{~L} / \mathrm{min}$ and the penetration-flow rate was $25 \mathrm{~mL} / \mathrm{min}$. The cross-flow ultrafiltration working pressure was kept at $5 \mathrm{~kg} / \mathrm{cm}^{2}$. In the concentration process, the volume concentration factor $\left(\mathrm{C}_{\mathrm{f}}\right)$ was kept at 10 (Equation (1)), in which the retentate flow was directed back to the feed bottle; this was the HMHS solution at the end of the separation. The penetration flow was directed to another container to be collected as the LMHS $(<1 \mathrm{kDa})$. The mass balances of the dissolved organic carbon (C content) and heavy metals were calculated by Equation (2). The HMHS and LMHS mass fractions were calculated following Equations (3) and (4).

$$
\begin{aligned}
& \mathrm{C}_{\mathrm{f}}=\frac{\mathrm{V}_{\mathrm{LMHS}}+\mathrm{V}_{\mathrm{HMHS}}}{\mathrm{V}_{\mathrm{HMHS}}}, \\
& \mathrm{R}(\%)=\frac{\mathrm{C}_{\text {HMHS }} \times \mathrm{V}_{\text {HMHS }}+\mathrm{C}_{\text {LMHS }} \times \mathrm{V}_{\text {LMHS }}}{\mathrm{C}_{\text {bulk }} \times \mathrm{V}_{\text {bulk }}} \times 100, \\
& \mathrm{M}_{\mathrm{HMHS}}(\%)=\frac{\mathrm{C}_{\text {HMHS }} \times \mathrm{V}_{\mathrm{HMHS}}}{\mathrm{C}_{\mathrm{HMHS}} \times \mathrm{V}_{\mathrm{HMHS}}+\mathrm{C}_{\mathrm{LMHS}} \times \mathrm{V}_{\mathrm{LMHS}}} \times 100 \\
& \mathrm{M}_{\mathrm{LMHS}}(\%)=100-\mathrm{M}_{\mathrm{HMHS}}(\%)
\end{aligned}
$$

where $C_{f}$ was the volume concentration factor. $R(\%)$ was the mass balance percentage of the separated mass (HMHS added to LMHS) divided by the feed mass (BHS) for DOC, $\mathrm{Cd}$, and Ni. $\mathrm{C}_{\mathrm{HMHS}}, \mathrm{C}_{\mathrm{LMHS}}$, and $C_{\text {bulk }}$ were the measured metal concentrations and $C$ content in the HMHS, LMHS, and BHS solutions, respectively. $\mathrm{V}_{\mathrm{HMHS}}, \mathrm{V}_{\mathrm{LMHS}}$, and $\mathrm{V}_{\text {bulk }}$ were the metal and DOC volumes for the separation procedure for the HMHS, LMHS and BHS solutions, respectively. $\mathrm{M}_{\mathrm{HMHS}}$ and $\mathrm{M}_{\mathrm{LMHS}}$ were the mass fractions of DOC and metals in the HMHS and LMHS solutions. The membrane was cleaned and preconditioned before each SHS separation experiment as recommended by manufacture protocol. The three SHS fractions were measured via DOC, UV-vis, and fluorescence spectroscopy.

\subsection{Dissolved Organic Carbon and Metals Measurement}

The BHS, HMHS, and LMHS C contents were measured with a TOC-V analyzer (Shimadzu, Japan). High concentrations of heavy metals and alkaline metals $(\mathrm{Ca}, \mathrm{Mg}, \mathrm{K}$, and $\mathrm{Na}$ ) were measured with an atomic absorption spectroscopy (AAS) (Hitachi, Z-2300, Japan). When the metal concentration was lower than the AAS detection limit, the metal concentration was measured with graphite furnace atomization (Hitachi, Z-3000, Japan).

\subsection{UV-Vis and Fluorescent Measurement}

The BHS and sized SHS solutions were diluted to $5 \mathrm{mg}-\mathrm{C} / \mathrm{L}$ with ultrapure water. The absorbance was measured with an ultraviolet/visible spectrophotometer (Hitachi, U-2900) and fluorescence spectra were recorded on a fluorescence spectrometer (Hitachi F-7000). The absorbance at 700-800 nm was set as the background value. The absorbance of the sample was subtracted from the average of the absorbance at 700-800 nm [30]. The UV-Vis spectrophotometric scanning wavelength was 800-200 nm.

The excitation/emission matrixes (EEMs) were generated by recording emission spectra from $250-550 \mathrm{~nm}$ at $2.0 \mathrm{~nm}$ steps for an excitation wavelength between $200-450 \mathrm{~nm}$ at $5 \mathrm{~nm}$ increments. The scanning rate was $2400 \mathrm{~nm} / \mathrm{min}$. The value of the blank sample was subtracted from the sample fluorescent data. The UV-Vis absorbance at $254 \mathrm{~nm}$ was $<0.2$ and the inner filter effect correction was ignored.

\subsection{Optical Index and Metal Binding Affinity Calculation}

The specific ultraviolet absorbance at $254 \mathrm{~nm}\left(\mathrm{SUVA}_{254}, \mathrm{~L} / \mathrm{mg}-\mathrm{C} / \mathrm{m}\right)$ is the absorbance of the sample at $254 \mathrm{~nm} \mathrm{UV} 254\left(\mathrm{~cm}^{-1}\right)$ divided by the $C$ content of the SHS sample (mg-C/L) multiplied 
by 100 [36]. The UV-Vis spectral slopes in the $275-295 \mathrm{~nm}$ and $350-400 \mathrm{~nm}$ spectral ranges were determined and were reported as $S_{275-295}$ to $S_{350-400}$. The slope ratio $S_{R}$ was calculated as the ratio of $S_{275-295}$ to $S_{350-400}$. $[30,37]$. The Fluorescence Index (FI) is the fluorescence intensity ratio of Em $=450$ to $\mathrm{Em}=500 \mathrm{~nm}$ at $\mathrm{Ex}=370 \mathrm{~nm}[31,32]$. The metal binding affinity ([Me]/[DOC] ratio, $\mu \mathrm{mol}-\mathrm{Me} / \mathrm{g}-\mathrm{C}$ ) was calculated as the metal concentration divided by the SHS C content.

\subsection{Statistic Analysis}

In this study, linear regression, step-wise regression, and the difference tests used the S-Plus software (V 6.2, Insightful Corporation, Seattle, WA, USA) at significance levels at $p<0.05$. Two group difference tests between HMHS and LMHS (such as, concentration, mass fraction, [Me]/[DOC] ratio, and indicators) were used in the t-test method. The three group difference tests used the ANOVA test method. Fluorescence indicators were calculated at R script developed by Lapworth and Kinniburgh [38]. The step-wise procedure, the measured [Me]/[DOC] ratio was set as the dependent parameter and the selected indicators were set as independent parameters. We then conducted the step-wise regression procedure to obtain the significant indicator and coefficients. Next, we used the predicted equation and significant indicators and coefficients to calculate the predicted $[\mathrm{Me}] /[\mathrm{DOC}]$ ratio.

\section{Results and Discussion}

\subsection{UV-Vis and Fluorescent Index}

Optical indicators have been used extensively and are effective tools for examining the chemical composition and structure of DOM and dissolved SHS $[3,9,10,16,39,40]$. Table 1 lists the SUVA $_{254}$, $\mathrm{S}_{\mathrm{R}}$, and FI values of BHS, HMHS, and LMHS. The SHS optical indices were comparable to reported values in soil solution, where $\mathrm{SUVA}_{254}$ values ranged from $0.38-7.18 \mathrm{~L} / \mathrm{mg}-\mathrm{C} / \mathrm{m}[3,9,10,16,40], \mathrm{S}_{\mathrm{R}}$ values ranged from $0.64-3.26[16,39]$, and FI values ranged from 1.08-2.03 [3,16,31].

Table 1. Optical indicators of three sized soil humic substances solutions $(n=24)$.

\begin{tabular}{cccc}
\hline Samples & SUVA $_{254}(\mathbf{L} / \mathbf{m g}-\mathbf{C} / \mathbf{m})$ & $\mathbf{S}_{\mathbf{R}}{ }^{*}$ & FI $^{*}$ \\
\hline BHS & $3.06 \pm 1.32$ & $0.52 \pm 0.16$ & $1.63 \pm 0.13$ \\
HMHS & $3.16 \pm 1.63$ & $0.54 \pm 0.18$ & $1.57 \pm 0.15$ \\
LMHS & $2.65 \pm 1.25$ & $0.40 \pm 0.17$ & $1.68 \pm 0.12$ \\
\hline
\end{tabular}

${ }^{*} p<0.05$; between high and low molecular weight soil humic substances

The SUVA 254 is positively correlated with the aromatic content [41]. When $\mathrm{SUVA}_{254}$ is $<3 \mathrm{~L} / \mathrm{mg}-\mathrm{C} / \mathrm{m}$, the SHS solution consists mainly of hydrophilic aromatic compounds, while when $\mathrm{SUVA}_{254}$ is $>4 \mathrm{~L} / \mathrm{mg}-\mathrm{C} / \mathrm{m}$, the composition of the SHS solution is dominated by hydrophobic compounds [34]. The average HMHS SUVA 254 value was higher than the average LMHS SUVA 254 value but insignificantly different $(p=0.23)$. The $\mathrm{SUVA}_{254}$ value showed that the SHS solution mainly contained hydrophilic and low aromatic compounds.

$S_{R}$ is the indicator of average molecular weight [30]. $S_{R}$ values show that HMHS was significantly greater than LMHS $(p=0.007)$. Although, Helms et al. [30] suggested that $S_{R}$ was negatively correlated with mean molecular weight, the $S_{R}$ of this study was significantly positively correlated with the SUVA $_{254}$ and significantly negatively correlated with the FI, respectively $\left(r=0.842\right.$ for $\mathrm{SUVA}_{254}$, $\mathrm{r}=-0.765$ for FI, $p<0.001, n=72$ ). HMHS had higher $S_{R}$ values than LMHS (Table 1 ), which confirmed that higher $S_{R}$ values had higher aromaticity, molecular weight and terrestrial sources in this study.

FI is the relative contribution of terrestrial sources [3,31,32,42]. FI values less than 1.4 indicated the HS had strong terrestrial sources and when larger than 1.9, had microbial sources [31,32]. HMHS and LMHS both had median terrestrial sources and HMHS had a higher terrestrial contribution than LMHS $(p=0.006)$. FI values had a significantly negative correlation with $\mathrm{SUVA}_{254}$ values $(\mathrm{r}=-0.735$, 
$p<0.001)$. The optical indices showed that the HMHS had higher aromaticity, average molecular weight, and terrestrial sources than LMHS.

\subsection{Soil Properties and Metal Concentration}

The soil basic properties of $\mathrm{pH}, \mathrm{OM}$, and TOC were $8.28 \pm 0.08 \%, 3.12 \pm 0.32 \%$, and $1.81 \pm 0.19 \%$, respectively for the 24 samples. The total $\mathrm{Ca}$ and Fe concentrations were $1.44 \pm 0.18 \mathrm{~g} / \mathrm{kg}$ and $21.8 \pm 4.5 \mathrm{~g} / \mathrm{kg}$, respectively. The concentrations of $\mathrm{Mg}$, $\mathrm{K}$, and Na were $316 \pm 30,395 \pm 47,64.7 \pm 12.7$, and $55.3 \pm 5.7 \mathrm{mg} / \mathrm{kg}$, respectively. The basic soil properties and main metal total concentrations were similar to those of general farm land soil $[4,12,43,44]$.

The BHS C content was $678 \pm 247 \mathrm{mg} / \mathrm{kg}$ and the BHS-C content $/ \mathrm{TOC}$ ratio was $3.7 \%$. In four agricultural soil tests by Fernández-Romero et al. [3], organic matter ranged from 4.3-15.6\%. The water extraction organic carbon (WEOC) was $80-620 \mathrm{mg} / \mathrm{kg}$ at room temperature; the WEOC/OM ratios were $0.12-0.40 \%$. In another study, Nkhili et al. [40] reported soil was extracted with different water temperature $\left(20,60\right.$, and $\left.80^{\circ} \mathrm{C}\right)$. The WEOC was $310-401 \mathrm{mg} / \mathrm{kg}$, and WEOC/TOC ratios were $0.93-1.16 \%$. The alkaline-extracted soil organic carbon in the study was slightly higher than water-extracted soil organic carbon at room temperature.

Table 2 lists the total concentrations of $\mathrm{Cd}, \mathrm{Cr}, \mathrm{Cu}, \mathrm{Ni}$, and $\mathrm{Zn}$ and the BHS concentrations of these heavy metals. The total metal concentrations are generally similar to the concentration of the uncontaminated agricultural soils $[4,11,43,44]$. The BHS concentration of $\mathrm{Cu}(1.19 \mathrm{mg} / \mathrm{kg})$ was higher than the concentrations of the other metals; all other metals were below $1.0 \mathrm{mg} / \mathrm{kg}$. The ratios of BHS to the total metal concentration shows that the ratios of $\mathrm{Cd}$ to $\mathrm{Cu}$ had higher ratios (15.4\% and $12.1 \%$, respectively) than the other metals $\mathrm{Ni}(1.07 \%)$, and both $\mathrm{Cr}$ and $\mathrm{Zn}<1 \%$. Cambier et al. [11] reported that "the ratios suggested that $\mathrm{Cu}$ and $\mathrm{Cd}$ preferentially combined with soil humic substances." Matong et al. [4] reported that three agricultural soils were sequentially extracted with acetic, ascorbic and hydrogen peroxide digestion. The exchangeable, and organic binding fractions were $52-61 \%$, and $24-32 \%$ for $\mathrm{Cd}$, and $\mathrm{Ni}$, respectively. The fractions were similar to our results that showed $\mathrm{Cd}$ was higher than $\mathrm{Ni}$ by exchangeable and organic fraction.

Table 2. Total and extracted bulk soil humic substances BHS heavy metal concentrations $(\mathrm{mg} / \mathrm{kg}, n=24)$.

\begin{tabular}{cccccc}
\hline & $\mathbf{C u}$ & $\mathbf{C d}$ & $\mathbf{C r}$ & $\mathbf{N i}$ & $\mathbf{Z n}$ \\
\hline Total & $9.89 \pm 0.69$ & $0.473 \pm 0.022$ & $19.3 \pm 2.4$ & $19.6 \pm 1.8$ & $73.2 \pm 28.5$ \\
BHS & $1.19 \pm 0.40$ & $0.073 \pm 0.026$ & $0.06 \pm 0.04$ & $0.21 \pm 0.08$ & $0.36 \pm 0.50$ \\
\hline
\end{tabular}

\subsection{Metal and SHS C Content and Distribution between HMHS and LMHS}

Table 3 lists the $\mathrm{C}$ content and concentrations of $\mathrm{Cd}$ and Ni of BHS, HMHS, and LMHS. This study investigated the metals $\mathrm{Cd}$ and $\mathrm{Ni}$ because they had accepted metal mass balance. However, the number of mass balances within reasonable range $(100 \pm 25 \%)[22,26,27,45]$ were 15,10 , and 6 for $\mathrm{Cr}$, $\mathrm{Cu}$, and $\mathrm{Zn}$, respectively for the separation. We ignored these data and the distribution of heavy metals $\mathrm{Cr}, \mathrm{Cu}$ and $\mathrm{Zn}$ was not investigated in later discussions. The mass balances of $\mathrm{DOC}, \mathrm{Cd}$, and $\mathrm{Ni}$ in the separation process were calculated following Equation (2). The average mass balances were between $83-90 \%$, which were within a reasonable range.

$\mathrm{Wu}$ and Tanous [45] separated lake water into three size-fractioned DOM, which included $0.1-0.7 \mu \mathrm{m}, 5 \mathrm{kDa}-0.1 \mu \mathrm{m}$, and $<5 \mathrm{kDa}$ fractions. The carbon mass balances were $89-109 \%$. Knoth de Zarruk et al. [46] reported that the four water-extracted soil and waste-borne DOM were separated into four size-fractioned DOM where the DOC mass balances were $80-151 \%$. Martin et al. [17] reported the DOC mass balances ranged from $85-98 \%$ separated with lagoon water DOM. Luan and Vadas [28] separated storm water and effluent DOM and the mass balances were 101-105\% for Cd [28]. Dabrin et al. [22] reported that five-sediment pore water DOM was separated into high molecular 
weight $(5 \mathrm{kDa}-0.45 \mu \mathrm{m})$ and low molecular weight DOM $(<5 \mathrm{kDa})$. The $\mathrm{Cd}$ and Ni mass balances were $50-220 \%$ (one exception $2000 \%$ ), and $100-280 \%$, respectively.

The average mass fractions of DOC, Cd, and Ni for HMHS and LMHS (Table 3, calculated by Equations (3) and (4)). The LMHS mass fractions were $82.9 \pm 6.7 \%$ and $55.9 \pm 19.3 \%$ for Cd and DOC, respectively. They were significantly greater than the HMHS mass fractions $(17.1 \pm 6.7 \%(\mathrm{Cd})$, $p<0.001 ; 44.1 \pm 19.3 \%$ (DOC), $p=0.038$ ). However, the Ni HMHS mass fraction $(57.7 \pm 18.5 \%)$ was significantly higher than the LMHS mass fraction $(42.3 \pm 18.5 \%, p=0.006)$. The mass fraction shows that Cd preferred to bind with LMHS, and Ni preferred to bind with HMHS.

Wang et al. [18] used a mixture of acetic acid (formic, and malic acid) to extract soil solutions, which were separated into HMHS $(1 \mathrm{kDa}-0.45 \mu \mathrm{m})$ and LMHS $(<1 \mathrm{kDa})$. Most metals had a high LMHS fraction (71\% (Cd) and $82 \%(\mathrm{Ni}))$. Ilina et al. [47] used ultrafiltration to separate water-extracted soil solution; the HMHS were $65 \%$, and $83 \%$ for $\mathrm{Cd}$, and $\mathrm{Ni}$, respectively. Hartland et al. [48] observed hyperalkaline cave drip-water, the HMW fractions $(1 \mathrm{kDa}-1.0 \mu \mathrm{m})$ were $64 \%$ for $\mathrm{Ni}$, which were similar to the results in our study. In four treatment processes in a municipal wastewater treatment plant, Hargreaves et al. [23] reported the HMW fractions $(1 \mathrm{kDa}-0.45 \mu \mathrm{m})$ were $67-75 \%$ for Ni [23]. In sediment pore water, Dabrin et al. [22] reported the HMW fractions ( $5 \mathrm{kDa}-0.45 \mu \mathrm{m})$ were $9-18 \%$, and $5-20 \%$ for $\mathrm{Cd}$, and $\mathrm{Ni}$, respectively (estimated from Figure). The mass fractions of high and low molecular weights in water extracted organic matter and DOM are variations. The fractions may depend on the matrix, type of metal, extraction solvent, extraction method and solid/liquid ratio, and separation method and conditions [18,49].

Table 3. Cadmium (Cd) and Nickel (Ni) and C content in BHS, HMHS, and LMHS solutions ( $n=24)$.

\begin{tabular}{cccc}
\hline Samples & DOC $(\mathbf{m g} / \mathrm{L})$ & Cd $(\mu \mathrm{g} / \mathrm{L})$ & Ni $(\mu \mathrm{g} / \mathrm{L})$ \\
\hline BHS & $(33.9 \pm 12.4)^{\mathrm{a}}$ & $(3.65 \pm 1.29)^{\mathrm{a}}, 1.04 \pm 0.38^{\mathrm{b}}$ & $(10.4 \pm 3.8)^{\mathrm{a}} ; 5.81 \pm 2.38^{\mathrm{b}}$ \\
HMHS & $(12.2 \pm 6.1,44 \%)^{\mathrm{a}}$ & $(0.55 \pm 0.25,17 \%)^{\mathrm{a}} ; 0.41 \pm 0.09^{\mathrm{b}}$ & $(5.1 \pm 2.6,58 \%)^{\mathrm{a}} ; 7.29 \pm 2.27^{\mathrm{b}}$ \\
LMHS & $(17.2 \pm 10.3,56 \%)^{\mathrm{a}}$ & $(2.61 \pm 0.74,83 \%)^{\mathrm{a}} ; 1.82 \pm 0.95^{\mathrm{b}}$ & $\left(3.6 \pm 2.1,42^{\mathrm{a}}\right)^{\mathrm{a}} ; 4.22 \pm 2.38^{\mathrm{b}}$ \\
Mass balance & $90 \pm 26 \%$ & $89 \pm 14 \%$ & $83 \pm 14 \%$ \\
\hline
\end{tabular}

${ }^{a}$ concentration $[\mathrm{C}$ content, $\mathrm{mg} / \mathrm{L}$ and metal $(\mu \mathrm{g} / \mathrm{L})]$, mass fraction $(\%) ;{ }^{\mathrm{b}}([\mathrm{Me}] /[\mathrm{DOC}])$ ratio, $\mu \mathrm{mol}-\mathrm{Me} / \mathrm{g}-\mathrm{OC}$.

\section{4. $[\mathrm{Me}] /[\mathrm{DOC}]$ Ratio}

The metal binding affinity, $[\mathrm{Me}] /[\mathrm{DOC}]$ ratio, was used to understand the difference in the binding ability of metals to DOM and WEOM [9,10,13-15]. Table 3 shows the [Me]/[DOC] ratios of $\mathrm{Cd}$ and $\mathrm{Ni}$ in BHS, HMHS, and LMHS solutions. The $[\mathrm{Me}] /[\mathrm{DOC}]$ ratios of HMHS to LMHS show that the $([\mathrm{Ni}] /[\mathrm{DOC}])_{\mathrm{HMHS}}$ ratio was significantly greater than $([\mathrm{Ni}] /[\mathrm{DOC}])_{\mathrm{LMHS}}$ $(p<0.001)$, but the $([\mathrm{Cd}] /[\mathrm{DOC}])_{\mathrm{HMHS}}$ ratio was significantly less than the $([\mathrm{Cd}] /[\mathrm{DOC}])_{\mathrm{LMHS}}$ $(p<0.001)$. The $[\mathrm{Me}] /[\mathrm{DOC}]_{\mathrm{BHS}}$ ratio was higher than the soil WEOM [Me]/[DOC] ratio as reported by Sauvé et al. [8]. The [Me]/[DOC] ratios were 0.025 , and $015 \mu \mathrm{mol} / \mathrm{g}-\mathrm{OC}$ ratios for $\mathrm{Cd}$ and $\mathrm{Ni}$, respectively in a forest soil WEOM solution. The low ratios were due to high soil carbon content $(50.1 \%)$ in the soil. The $[\mathrm{Ni}] /[\mathrm{DOC}]$ and $[\mathrm{Cd}] /[\mathrm{DOC}]$ ratios were comparable to natural water DOM samples reported by Baken et al. [13], which were $1.6 \pm 0.0$ to $4.1 \pm 1.5 \mu \mathrm{mol} / \mathrm{g}-\mathrm{OC}$ for $\mathrm{Ni}$, and $1.2 \pm 0.2$ to $3.0 \pm 0.2 \mu \mathrm{mol} / \mathrm{g}-\mathrm{OC}$ for $\mathrm{Cd}$; however, the $[\mathrm{Me}] /[\mathrm{DOC}]$ ratios were lower than those impacted by anthropogenically-influenced DOM samples, which were $5.8 \pm 1.3$ to $14.7 \pm 0.2 \mu \mathrm{mol} / \mathrm{g}-\mathrm{OC}$ for $\mathrm{Ni}$ and $4.4 \pm 0.6$ to $12.5 \pm 0.3 \mu \mathrm{mol} / \mathrm{g}$-OC for Cd. In a WWTP final effluent, Hargreaves et al. [23] reported that the $[\mathrm{Ni}] /[\mathrm{DOC}]$ ratios were 4.6 and $8.3 \mu \mathrm{mol} / \mathrm{g}$-OC for the low $(<1 \mathrm{kDa})$ and high $(>1 \mathrm{kDa})$ molecular weight DOM.

\subsection{Correlation between $[\mathrm{Me}] /[\mathrm{DOC}]$ Ratios and Optical Indices}

We used the Pearson correlation analysis to explore the SHS factors affecting the [Me]/[DOC] ratios. Table 4 shows the correlation coefficients between $[\mathrm{Me}] /[\mathrm{DOC}]$ ratios and selected indicators for BHS, HMHS, and LMHS. The ratios of $[\mathrm{Cd}, \mathrm{Ni}] /[\mathrm{DOC}]_{\mathrm{BHS}}$ and $[\mathrm{Cd}, \mathrm{Ni}] /[\mathrm{DOC}]_{\mathrm{LMHS}}$ had a significant 
correlation with the $\mathrm{C}$ content, indices $\mathrm{S}_{\mathrm{R}}$ and $\mathrm{SUVA}_{254}(p<0.02)$. Furthermore, $[\mathrm{Cd}] /[\mathrm{DOC}]_{\mathrm{LMHS}}$ had a significantly negative correlation with the index FI $(p=0.047)$. However, there was no significant correlation between $[\mathrm{Me}] /[\mathrm{DOC}]_{\mathrm{HMHS}}$ and optical indicators or the $\mathrm{C}$ content.

Table 4. Correlation coefficients of $[\mathrm{Me}] /[\mathrm{DOC}]$ ratios with the selected optical indicators and C contents.

\begin{tabular}{|c|c|c|c|c|}
\hline Samples & DOC & SUVA $_{254}$ & $S_{R}$ & FI \\
\hline$[\mathrm{Cd}] /[\mathrm{DOC}]_{\text {Bulk }}(n=24)$ & $-0.67^{* * *}$ & 0.49 * & 0.50 * & -0.22 \\
\hline$[\mathrm{Ni}] /[\mathrm{DOC}]_{\text {Bulk }}(n=24)$ & $-0.68^{* * *}$ & 0.49 * & $0.45^{*}$ & -0.21 \\
\hline$[\mathrm{Cd}] /[\mathrm{DOC}]_{\text {LMHS }}(n=24)$ & $-0.85^{* * *}$ & $0.86^{* * *}$ & $0.61^{* * *}$ & $-0.51^{* *}$ \\
\hline$[\mathrm{Ni}] /[\mathrm{DOC}]_{\text {LMHS }}(n=24)$ & $-0.48 *$ & $0.68^{* * *}$ & $0.68^{* * *}$ & -0.14 \\
\hline$[\mathrm{Cd}] /[\mathrm{DOC}]_{\text {HMHS }}(n=24)$ & -0.37 & 0.06 & -0.15 & 0.22 \\
\hline$[\mathrm{Ni}] /[\mathrm{DOC}]_{\text {HMHS }}(n=24)$ & -0.18 & -0.05 & 0.29 & -0.16 \\
\hline$[\mathrm{Cd}] /[\mathrm{DOC}]_{\text {Total }}(n=72)$ & $-0.248 *$ & $0.233 *$ & 0.021 & 0.114 \\
\hline$[\mathrm{Ni}] /[\mathrm{DOC}]_{\text {Total }}(n=72)$ & $-0.361^{* *}$ & $0.346^{* *}$ & $0.568^{* * *}$ & -0.263 * \\
\hline
\end{tabular}

The ratios of $[\mathrm{Me}] /[\mathrm{DOC}]_{\mathrm{HMHS}}$ had no correlation with the HMHS optical indicators, which may be due to the complex composition of HMHS containing biopolymers [42]. It is believed that humic acid (HA) and fulvic acid (FA) contain various functional groups that have a strong metal-binding ability. The HA and FA molecular weights range from sub-kDa to several $\mathrm{kDa}[1,42]$. The LMHS indices $S_{R}$ and $S_{U V A}{ }_{254}$ had a strong correlation with $[C d, N i] /[D O C]$ ratios, which suggested that LMHS $(<1 \mathrm{kDa})$, still containing low molecular weight HA and FA, have the potential to bind to $\mathrm{Cd}$ and Ni. Meanwhile, the $([\mathrm{Cd}] /[\mathrm{DOC}])_{\mathrm{LMHS}}$ ratio had a negative correlation with the terrestrial sources index, which suggested that the HS high terrestrial sources had a high Cd-HS binding ability $[50,51]$. The ratios of $[\mathrm{Cd}, \mathrm{Ni}] /[\mathrm{DOC}]_{\mathrm{HMHS}}$ were insignificantly correlated with the indices, which implied a complex composition of HMHS, with aromatic content and molecular weight, cannot predict the Me-HS binding ability. The high molecular weight sources may contain biopolymers.

Table 4 lists the correlation coefficients between the combined optical indices of BHS, HMHS, and LMHS and the $[\mathrm{Me}] /[\mathrm{DOC}]$ ratios of the three sized solution. The results showed that the $[C d] /[D O C]$ ratio was only weakly positive when correlated with $\mathrm{SUVA}_{254}$ and was insignificantly correlated with the FI and $S_{\mathrm{R}}$ indicators. The $[\mathrm{Ni}] /[\mathrm{DOC}]$ ratios have a weak to moderate correlation with the three selected indicators. High aromaticity, large molecular weight, and a high terrestrial source contribution in SHS increased the Ni-SHS binding ability. The $[\mathrm{Cd}, \mathrm{Ni}] /[\mathrm{DOC}]$ ratios were significantly negative when correlated with $C$ content as previously reported $[9,10]$.

Previous studies reported that the correlation between the $[\mathrm{Me}] /[\mathrm{DOC}]$ ratio and the optical indicators mainly focused on the aqueous phase and soil bulk solution. For example, the $[\mathrm{Cu}] /[\mathrm{DOC}]$ ratio in soil water-extracted organic matter had a significant positive correlation with $\mathrm{SUVA}_{254}$ and a negative correlation with $\mathrm{C}$ content $[9,10]$. In natural water $\mathrm{DOM}$, ratios of $[\mathrm{Cu}, \mathrm{Fe}, \mathrm{Zn}] /[\mathrm{DOC}]$ had a significantly positive correlation with $\mathrm{SUVA}_{254}$ values. However, in water DOM affected by effluent of WTP, the [Me]/[DOC] ratios did not show correlations with $\mathrm{SUVA}_{254}$ [15]. In studied natural water DOM, influenced by anthropogenic input, the DOM tests demonstrated that the $\mathrm{SUVA}_{254}$ values of natural water DOM had a significant positive correlation with ratios of [Cd, $\mathrm{Cu}, \mathrm{Ni}, \mathrm{Zn}] /[\mathrm{DOC}]$; however, anthropogenic-affected DOM SUVA 254 values had no correlation with ratios of $[\mathrm{Cd}, \mathrm{Cu}, \mathrm{Ni}$, $\mathrm{Zn}] /[\mathrm{DOC}][13]$.

We used a step-wise multilinear regression to investigate the correlations between the total indicators and total [Me]/[DOC] ratios in combined BHS, HMHS, and LMHS solutions. The multilinear regression equation is shown in Table 5 . The predicted $[\mathrm{Me}] /[\mathrm{DOC}]$ ratios used the regression results with optical indices; the measured $[\mathrm{Me}] /[\mathrm{DOC}]$ ratios are shown in Figure 1a,b. The correlation coefficients between the predicted $[\mathrm{Me}] /[\mathrm{DOC}]$ ratio used multiple indicators from multilinear regression. Table 5 shows two types of regression equations; one was predicted with the three selected indicators and the other equation predicted with the three indicators and the $C$ content. When the $C$ content was 
added as a predicted indicator, the determined coefficients were slightly increased compared to the regression without the $C$ content. The $C$ content coefficient was negative, which is the same as the result in Table 4 and is consistent with the previous study $[9,10]$.

Table 5. Predicted equations of [Me]/[DOC] ratio fitted with optical indicators.

\begin{tabular}{ccc}
\hline Fitting Equations & $\mathbf{R}$ & $p$ \\
\hline$[\mathrm{Cd}] /[\mathrm{DOC}]=-4.825-1.601 \times \mathrm{S}_{\mathrm{R}}+0.533 \times \mathrm{SUVA}_{254}+3.159 \times \mathrm{FI}$ & 0.509 & $<0.001$ \\
{$[\mathrm{Cd}] /[\mathrm{DOC}]=-3.838-1.767 \times \mathrm{S}_{\mathrm{R}}+0.515 \times \mathrm{SUVA}_{254}+2.762 \times \mathrm{FI}-0.0104 \times[\mathrm{DOC}]$} & 0.535 & $<0.001$ \\
{$[\mathrm{Ni}] /[\mathrm{DOC}]=-10.936+16.469 \times \mathrm{S}_{\mathrm{R}}-0.668 \times \mathrm{SUVA}_{254}+6.635 \times \mathrm{FI}$} & 0.652 & $<0.001$ \\
{$[\mathrm{Ni}] /[\mathrm{DOC}]=-5.497+15.554 \times \mathrm{SR}-0.769 \times \mathrm{SUVA}^{2} 54+4.476 \times \mathrm{FI}-0.0573 \times[\mathrm{DOC}]$} & 0.712 & $<0.001$ \\
\hline
\end{tabular}

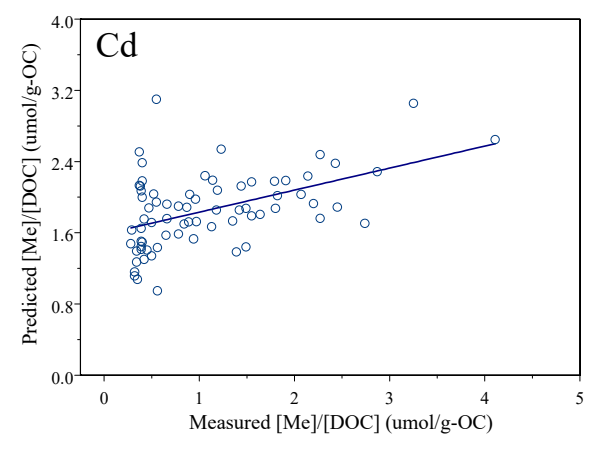

(a)

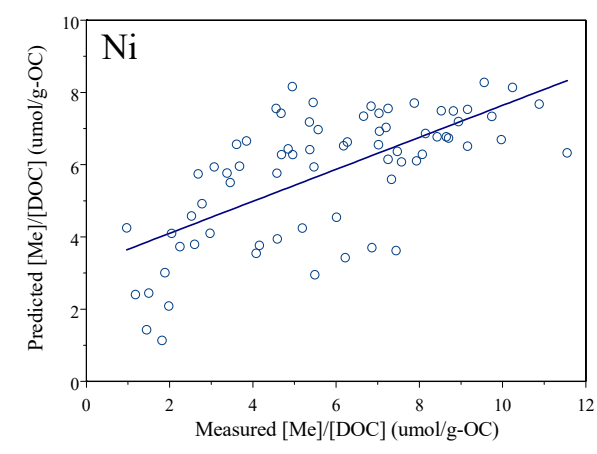

(b)

Figure 1. The linear relationship of the measured $[\mathrm{Me}] /[\mathrm{DOC}]$ ratio and predicted $[\mathrm{Me}] /[\mathrm{DOC}]$ ratio using the selected indicators for $\mathrm{Cd}(\mathbf{a})$ and $\mathrm{Ni}(\mathbf{b})$.

The $[C d] /[D O C]$ ratio predictive equation shows that the $\mathrm{SUVA}_{254}$ coefficient had a positive value and the $S_{R}$ had negative value. However, the $[\mathrm{Ni}] /[\mathrm{DOC}]$ ratio predictive equation coefficients were in contrast to the $[\mathrm{Cd}] /[\mathrm{DOC}]$ ratio predictive equation; the $\mathrm{SUVA}_{254}$ coefficients had a negative value and $S_{R}$ had a positive value. The reverse coefficients for $\mathrm{Cd}$ and Ni suggested that the influencing Me-HS binding factors could be different for different metals. In the studied HS, Cd preferred combining with low molecular weight HS, so it is negatively correlated with the molecular weight indicator $\left(S_{R}\right)$ and positively correlated with aromaticity $\left(\mathrm{SUVA}_{254}\right)$. However, Ni preferred combining with high molecular weight; therefore, it positively correlated with the molecular weight indicator $\left(S_{R}\right)$ and negatively correlated with aromaticity $\left(\mathrm{SUVA}_{254}\right)$. The coefficient values of FI for both $\mathrm{Cd}$ and Ni were positive, which indicated that higher terrestrial sources correlated with lower Me-HS binding ability. The Cd and Ni preferred to combine with the SHS microbial source. The results of the [Me]/[DOC] ratio predicted by the indicators show that the combination of Me-SHS is affected by both the C content and the chemical structure of the SHS.

\section{Conclusions}

Separating soil SHS into different molecular weights allows understanding of the different chemical structure and composition of HS and HS-Me binding ability between the HMHS and LMHS. The Cd and Ni were not evenly distributed in HMHS and LMHS. The separated SHS showed that Cd favored binding with LMHS, but Ni favored binding with HMHS. The optical indices had a significant correlation with the $[\mathrm{Me}] /[\mathrm{DOC}]$ ratios of BHS and LMHS. However, the $[\mathrm{Me}] /[\mathrm{DOC}]$ ratio of HMHS had no significant correlation with the optical indices. Possibly, because of the complex composition of HMHS, aromaticity and a terrestrial source cannot explain the Me-SHS binding ability. The multilinear regression used with the selected optical indices were able to predict the measured [Me]/[DOC] ratios. In addition, the indicator coefficient affected the $[\mathrm{Cd}, \mathrm{Ni}] /[\mathrm{DOC}]$ ratios and had a reverse relationship. 
The results show that the optical indices can distinguish the chemical composition and structure of different size SHS and predict the binding ability of Me-SHS.

Author Contributions: Methodology and software: Y.-L.Y., S.-H.H., and T.-P.C.; Investigation and analysis: S.-H.H., W.-S.H., and T.-P.C.; Writing—original draft preparation, review, and editing: Y.-L.Y., T.-C.C., W.-S.H.

Acknowledgments: We sincerely thank Taiwan Chia-Nan Irrigation Association for financial support and provided the experimental site.

Conflicts of Interest: The authors declare no conflict of interest.

\section{References}

1. Aiken, G.R.; Hsu-Kim, H.; Ryan, J.N. Influence of dissolved organic matter on the environmental fate of metals, nanoparticles, and colloids. Environ. Sci. Technol. 2011, 45, 3196-3201. [CrossRef] [PubMed]

2. Lehmann, J.; Kleber, M. The contentious nature of soil organic matter. Nature 2015, 528, 60. [CrossRef] [PubMed]

3. Fernández-Romero, M.; Clark, J.; Collins, C.; Parras-Alcántara, L.; Lozano-García, B. Evaluation of optical techniques for characterising soil organic matter quality in agricultural soils. Soil Tillage Res. 2016, 155, 450-460. [CrossRef]

4. Matong, J.M.; Nyaba, L.; Nomngongo, P.N. Fractionation of trace elements in agricultural soils using ultrasound assisted sequential extraction prior to inductively coupled plasma mass spectrometric determination. Chemosphere 2016, 154, 249-257. [CrossRef] [PubMed]

5. Gustafsson, J.P.; Pechová, P.; Berggren, D. Modeling metal binding to soils: The role of natural organic matter. Environ. Sci. Technol. 2003, 37, 2767-2774. [CrossRef] [PubMed]

6. Dijkstra, J.J.; Meeussen, J.C.; Comans, R.N. Leaching of heavy metals from contaminated soils: An experimental and modeling study. Environ. Sci. Technol. 2004, 38, 4390-4395. [CrossRef] [PubMed]

7. Zhou, T.; Wu, L.; Luo, Y.; Christie, P. Effects of organic matter fraction and compositional changes on distribution of cadmium and zinc in long-term polluted paddy soils. Environ. Pollut. 2018, 232, 514-522. [CrossRef] [PubMed]

8. Sauvé, S.; Manna, S.; Turmel, M.C.; Roy, A.G.; Courchesne, F. Solid-solution partitioning of $\mathrm{Cd}, \mathrm{Cu}, \mathrm{Ni}$, $\mathrm{Pb}$, and $\mathrm{Zn}$ in the organic horizons of a forest soil. Environ. Sci. Technol. 2003, 37, 5191-5196. [CrossRef] [PubMed]

9. Amery, F.; Degryse, F.; Degeling, W.; Smolders, E.; Merckx, R. The copper-mobilizing-potential of dissolved organic matter in soils varies 10-fold depending on soil incubation and extraction procedures. Environ. Sci. Technol. 2007, 41, 2277-2281. [CrossRef]

10. Amery, F.; Degryse, F.; Cheyns, K.; de Troyer, I.; Mertens, J.; Merckx, R.; Smolders, E. The UV-absorbance of dissolved organic matter predicts the fivefold variation in its affinity for mobilizing $\mathrm{Cu}$ in an agricultural soil horizon. Eur. J. Soil Sci. 2008, 59, 1087-1095. [CrossRef]

11. Cambier, P.; Pot, V.; Mercier, V.; Michaud, A.; Benoit, P.; Revallier, A.; Houot, S. Impact of long-term organic residue recycling in agriculture on soil solution composition and trace metal leaching in soils. Sci. Total Environ. 2014, 499, 560-573. [CrossRef] [PubMed]

12. Krishnamurti, G.S.; Naidu, R. Solid-solution speciation and phytoavailability of copper and zinc in soils. Environ. Sci. Technol. 2002, 36, 2645-2651. [CrossRef] [PubMed]

13. Baken, S.; Degryse, F.; Verheyen, L.; Merckx, R.; Smolders, E. Metal complexation properties of freshwater dissolved organic matter are explained by its aromaticity and by anthropogenic ligands. Environ. Sci. Technol. 2011, 45, 2584-2590. [CrossRef] [PubMed]

14. Fujii, M.; Imaoka, A.; Yoshimura, C.; Waite, T. Effects of molecular composition of natural organic matter on ferric iron complexation at circumneutral pH. Environ. Sci. Technol. 2014, 48, 4414-4424. [CrossRef] [PubMed]

15. Kikuchi, T.; Fujii, M.; Terao, K.; Jiwei, R.; Lee, Y.P.; Yoshimura, C. Correlations between aromaticity of dissolved organic matter and trace metal concentrations in natural and effluent waters: A case study in the Sagami River Basin, Japan. Sci. Total Environ. 2017, 576, 36-45. [CrossRef] [PubMed]

16. Gao, J.; Liang, C.; Shen, G.; Lv, J.; Wu, H. Spectral characteristics of dissolved organic matter in various agricultural soils throughout China. Chemosphere 2017, 176, 108-116. [CrossRef] [PubMed]

17. Martin, J.M.; Dai, M.H.; Cauwet, G. Significance of colloids in the biogeochemical cycling of organic carbon and trace metals in the Venice Lagoon (Italy). Limnol. Oceanogr. 1995, 40, 119-131. [CrossRef] 
18. Wang, W.; Wen, B.; Zhang, S.; Shan, X.Q. Distribution of heavy metals in water and soil solutions based on colloid-size fractionation. Int. J. Environ. Anal. Chem. 2003, 83, 357-365. [CrossRef]

19. Worms, I.A.; Szigeti, Z.A.G.; Dubascoux, S.; Lespes, G.; Traber, J.; Sigg, L.; Slaveykova, V.I. Colloidal organic matter from wastewater treatment plant effluents: Characterization and role in metal distribution. Water Res. 2010, 44, 340-350. [CrossRef]

20. Jarvie, H.; Neal, C.; Rowland, A.; Neal, M.; Morris, P.; Lead, J.; Lawlor, A.; Woods, C.; Vincent, C.; Guyatt, H. Role of riverine colloids in macronutrient and metal partitioning and transport, along an upland-lowland land-use continuum, under low-flow conditions. Sci. Total Environ. 2012, 434, 171-185. [CrossRef]

21. Vasyukova, E.; Pokrovsky, O.S.; Viers, J.; Dupré, B. New operational method of testing colloid complexation with metals in natural waters. Appl. Geochem. 2012, 27, 1226-1237. [CrossRef]

22. Dabrin, A.; Roulier, J.L.; Coquery, M. Colloidal and truly dissolved metal (oid) fractionation in sediment pore waters using tangential flow filtration. Appl. Geochem. 2013, 31, 25-34. [CrossRef]

23. Hargreaves, A.J.; Vale, P.; Whelan, J.; Constantino, C.; Dotro, G.; Campo, P.; Cartmell, E. Distribution of trace metals $(\mathrm{Cu}, \mathrm{Pb}, \mathrm{Ni}, \mathrm{Zn})$ between particulate, colloidal and truly dissolved fractions in wastewater treatment. Chemosphere 2017, 175, 239-246. [CrossRef] [PubMed]

24. Wu, J.; Zhang, H.; Shao, L.M.; He, P.J. Fluorescent characteristics and metal binding properties of individual molecular weight fractions in municipal solid waste leachate. Environ. Pollut. 2012, 162, 63-71. [CrossRef] [PubMed]

25. McPhedran, K.N.; Seth, R.; Drouillard, K.G. Investigation of Hydrophobic Organic Carbon (HOC) partitioning to $1 \mathrm{kDa}$ fractionated municipal wastewater colloids. Environ. Sci. Technol. 2013, 47, 2548-2553. [CrossRef]

26. Xu, H.; Zou, L.; Guan, D.; Li, W.; Jiang, H. Molecular weight-dependent spectral and metal binding properties of sediment dissolved organic matter from different origins. Sci. Total Environ. 2019, 665, 828-835. [CrossRef]

27. Wen, L.S.; Santschi, P.; Gill, G.; Paternostro, C. Estuarine trace metal distributions in Galveston Bay: Importance of colloidal forms in the speciation of the dissolved phase. Mar. Chem. 1999, 63, 185-212. [CrossRef]

28. Luan, H.; Vadas, T.M. Size characterization of dissolved metals and organic matter in source waters to streams in developed landscapes. Environ. Pollut. 2015, 197, 76-83. [CrossRef]

29. Wang, W.; Chen, M.; Guo, L.; Wang, W.X. Size partitioning and mixing behavior of trace metals and dissolved organic matter in a South China estuary. Sci. Total Environ. 2017, 603, 434-444. [CrossRef]

30. Helms, J.R.; Stubbins, A.; Ritchie, J.D.; Minor, E.C.; Kieber, D.J.; Mopper, K. Absorption spectral slopes and slope ratios as indicators of molecular weight, source, and photobleaching of chromophoric dissolved organic matter. Limnol. Oceanogr. 2008, 53, 955-969. [CrossRef]

31. McKnight, D.M.; Boyer, E.W.; Westerhoff, P.K.; Doran, P.T.; Kulbe, T.; Andersen, D.T. Spectrofluorometric characterization of dissolved organic matter for indication of precursor organic material and aromaticity. Limnol. Oceanogr. 2001, 46, 38-48. [CrossRef]

32. Birdwell, J.E.; Engel, A.S. Characterization of dissolved organic matter in cave and spring waters using UV-Vis absorbance and fluorescence spectroscopy. Org. Geochem. 2010, 41, 270-280. [CrossRef]

33. Huguet, A.; Vacher, L.; Relexans, S.; Saubusse, S.; Froidefond, J.M.; Parlanti, E. Properties of fluorescent dissolved organic matter in the Gironde Estuary. Org. Geochem. 2009, 40, 706-719. [CrossRef]

34. Matilainen, A.; Gjessing, E.T.; Lahtinen, T.; Hed, L.; Bhatnagar, A.; Sillanpää, M. An overview of the methods used in the characterisation of natural organic matter (NOM) in relation to drinking water treatment. Chemosphere 2011, 83, 1431-1442. [CrossRef] [PubMed]

35. Derrien, M.; Yang, L.; Hur, J. Lipid biomarkers and spectroscopic indices for identifying organic matter sources in aquatic environments: A review. Water Res. 2017, 112, 58-71. [CrossRef]

36. Hansen, A.M.; Kraus, T.E.; Pellerin, B.A.; Fleck, J.A.; Downing, B.D.; Bergamaschi, B.A. Optical properties of dissolved organic matter (DOM): Effects of biological and photolytic degradation. Limnol. Oceanogr. 2016, 61, 1015-1032. [CrossRef]

37. Shen, Y.; Chapelle, F.H.; Strom, E.W.; Benner, R. Origins and bioavailability of dissolved organic matter in groundwater. Biogeochemistry 2015, 122, 61-78. [CrossRef]

38. Lapworth, D.J.; Kinniburgh, D. An R script for visualising and analysing fluorescence excitation-emission matrices (EEMs). Comput. Geosci. 2009, 35, 2160-2163. [CrossRef]

39. Gao, S.J.; Zhao, C.; Shi, Z.H.; Zhong, J.; Liu, J.G.; Li, J.Q. Spectroscopic characteristics of dissolved organic matter in afforestation forest soil of Miyun District, Beijing. J. Anal. Methods Chem. 2016, 2016. [CrossRef] 
40. Nkhili, E.; Guyot, G.; Vassal, N.; Richard, C. Extractability of water-soluble soil organic matter as monitored by spectroscopic and chromatographic analyses. Environ. Sci. Pollut. Res. 2012, 19, 2400-2407. [CrossRef]

41. Weishaar, J.L.; Aiken, G.R.; Bergamaschi, B.A.; Fram, M.S.; Fujii, R.; Mopper, K. Evaluation of specific ultraviolet absorbance as an indicator of the chemical composition and reactivity of dissolved organic carbon. Environ. Sci. Technol. 2003, 37, 4702-4708. [CrossRef] [PubMed]

42. He, W.; Chen, M.; Park, J.E.; Hur, J. Molecular diversity of riverine alkaline-extractable sediment organic matter and its linkages with spectral indicators and molecular size distributions. Water Res. 2016, 100, 222-231. [CrossRef] [PubMed]

43. Impellitteri, C.A.; Lu, Y.; Saxe, J.K.; Allen, H.E.; Peijnenburg, W.J. Correlation of the partitioning of dissolved organic matter fractions with the desorption of $\mathrm{Cd}, \mathrm{Cu}, \mathrm{Ni}, \mathrm{Pb}$ and $\mathrm{Zn}$ from 18 Dutch soils. Environ. Int. 2002, 28, 401-410. [CrossRef]

44. Jalali, M.; Hemati, N. Chemical fractionation of seven heavy metals $(\mathrm{Cd}, \mathrm{Cu}, \mathrm{Fe}, \mathrm{Mn}, \mathrm{Ni}, \mathrm{Pb}$, and $\mathrm{Zn})$ in selected paddy soils of Iran. Paddy Water Environ. 2013, 11, 299-309. [CrossRef]

45. Wu, F.; Tanoue, E. Molecular mass distribution and fluorescence characteristics of dissolved organic ligands for copper (II) in Lake Biwa, Japan. Org. Geochem. 2001, 32, 11-20. [CrossRef]

46. De Zarruk, K.K.; Scholer, G.; Dudal, Y. Fluorescence fingerprints and Cu2+-complexing ability of individual molecular size fractions in soil-and waste-borne DOM. Chemosphere 2007, 69, 540-548. [CrossRef] [PubMed]

47. Ilina, S.M.; Lapitskiy, S.A.; Alekhin, Y.V.; Viers, J.; Benedetti, M.; Pokrovsky, O.S. Speciation, size fractionation and transport of trace elements in the continuum soil water-mire-humic lake-river-large oligotrophic lake of a Subarctic watershed. Aquat. Geochem. 2016, 22, 65-95. [CrossRef]

48. Hartland, A.; Fairchild, I.J.; Lead, J.R.; Zhang, H.; Baalousha, M. Size, speciation and lability of NOM-metal complexes in hyperalkaline cave dripwater. Geochim. Cosmochim. Acta 2011, 75, 7533-7551. [CrossRef]

49. Wenming, X.; Zhang, S.; Lin, R.; Mingyue, Y.; Weiming, S.; Zhang, H.; Weihua, L. Evaluating soil dissolved organic matter extraction using three-dimensional excitation-emission matrix fluorescence spectroscopy. Pedosphere 2017, 27, 968-973.

50. Pontoni, L.; van Hullebusch, E.D.; Fabbricino, M.; Esposito, G.; Pirozzi, F. Assessment of trace heavy metals dynamics during the interaction of aqueous solutions with the artificial OECD soil: Evaluation of the effect of soil organic matter content and colloidal mobilization. Chemosphere 2016, 163, 382-391. [CrossRef]

51. Yu, Y.; Wan, Y.; Camara, A.Y.; Li, H. Effects of the addition and aging of humic acid-based amendments on the solubility of $\mathrm{Cd}$ in soil solution and its accumulation in rice. Chemosphere 2018, 196, 303-310. [CrossRef] [PubMed] 